\title{
Talajnedvesség mérése mikrohullámú Michelson-féle interferométerrel
}

\author{
${ }^{1}$ UJFALUDI LÁSZLÓ, ${ }^{2}$ RAJKAI KÁLMÁN, ${ }^{1}$ VIDA JÓZSEF, \\ ${ }^{3}$ SZOMBATHY CSABA és ${ }^{1}$ ZOLLER GÁBOR \\ ${ }^{1}$ Eszterházy Károly Főiskola, Eger, \\ ${ }^{2}$ MTA Talajtani és Agrokémiai Kutatóintézet, Budapest és \\ ${ }^{3}$ Budapesti Müszaki és Gazdaságtudományi Egyetem, Budapest
}

\begin{abstract}
A talajra vonatkozó mérések közül a nedvességtartalom meghatározása talán a leggyakoribb, mert a nedvességadatok felhasználása igen széleskörü (növénytermesztés, öntözés, környezetvédelem stb.). A talajvizsgálati módszerek közül is a nedvességmérési módszerek választéka a legszélesebb (BUZÁs, 1993). A mérési módszerek nagy száma mutatja a folytonos igényt megbízható, gyors és széles körben alkalmazható nedvességmérési módszerekre. A hagyományosan elfogadott, ún. szárítószekrényes módszer legfőbb hátránya, hogy a terepi mintavételt követő 48 órai laboratóriumi szárítás után, azaz 2-3 nap múlva szolgáltat eredményt. Az 1970es évektől az izotópos módszerek közül a neutronszóródásos mérés vált nemzetközileg elfogadott helyszíni, közvetlen eredményt szolgáltató talajnedvesség-mérési módszerré. Az izotóphasználati és szállítási engedélyhez kötött módszert az 1990-es évektől az elektromos nedvességmérési módszerek (TDR és FD technikák) vették át (RAJKAI, 2004).

Az elektromos nedvességmérési megoldások a talajok dielektromos jellemzői alapján állapítják meg a talaj aktuális nedvességtartalmát. Minthogy a talaj dielektromos állandójának értéke elsősorban a talajban lévő víz mennyiségétől függ, az elektromos mérési módszerek a dielektromos állandó mérésére irányulnak. Ismert, hogy a száraz talaj dielektromos állandójának $(\varepsilon)$ értéke 2 és 5 közötti, míg a tiszta vízé $18{ }^{\circ} \mathrm{C}$-on 81 (DIRKSEN, 1999). A víztelített talajoké a szemcseösszetétel és az agyagásvány-típustól függően 25 és 45 között változik. A talaj dielektromos állandója, a talaj- $\varepsilon$ értéke - indirekt módon - a talaj nedvességtartalmával arányos. A talajtanban a talaj- $\varepsilon$ - és azon keresztül a nedvesség - mérésére a bemutatásra kerülő ún. Michelson-interferométeres mérési eljárást tudomásunk szerint még nem alkalmazták.

A Michelson-Morley kísérletet a fizikatörténet legjelentősebb kísérletei között tartják számon, mert olyan kísérleti bizonyítékokat szolgáltatott, amelyek a speciális relativitáselmélet megalapozását segítették elő.
\end{abstract}

Postai cím: UJFALUDI LÁSZLÓ, Eszterházy Károly Főiskola Fizika Tanszék, 3300 Eger, Leányka u. 4.E-mail: physics@ekft.hu 
A klasszikus Michelson-interferométer optikai eszköz, amelyet a fénysugarak interferencia-vizsgálatára használtak. A jóval később kifejlesztett mikrohullámú interferométer elrendezése az optikaihoz hasonló, de ebben a fényforrást és a leképező ernyőt mikrohullámú adó és vevő helyettesíti.

Kísérleteinkben azt kívántuk megállapítani, hogy a mikrohullámú berendezéssel kimérhetö-e a különböző nedvességtartalmú homoktalaj dielektromos állandója.

\section{Anyag és módszer}

\section{Dielektromos állandó mérése mikrohullámú Michelson-interferométerrel}

A mikrohullámú Michelson-interferométert régóta kiterjedten használják különböző anyagok $\varepsilon$ relatív dielektromos állandójának meghatározására (PATKÓ, 1991). A berendezés elrendezésének vázlata az 1. ábrán, képe a 2. ábrán látható. Az A adó által kibocsátott mikrohullámot az útjába tett $\mathrm{F}$ hullámosztó kettéosztja, és azok a $\mathrm{T}_{1}$, ill. a $\mathrm{T}_{2}$ tükörröl visszaverödve a $\mathrm{V}$ vevőbe jutnak (1. ábra). A $\mathrm{T}_{2}$ tükör mozgatásával a két hullám interferenciáját úgy változtatjuk, hogy a vevőben maximális amplitúdó értéket kapjunk. A mérendő próbatestet - amelynek a dielektromos állandóját akarjuk meghatározni - a $\mathrm{T}_{2}$ tükör és a hullámosztó közé állítjuk. A próbatest dielektromos állandója a korábbi interferenciaképet megváltoztatja és a maximum újbóli beállításához a $T_{2}$ tükröt $\mathrm{x}$ távolsággal el kell tolni. A talaj- $\varepsilon$ az x eltolás és a próbatest vastagsága ismeretében számítható (PATKÓ, 1991):

$$
\varepsilon=\left(1+\frac{x}{d}\right)^{2}
$$

ahol: $d$ a próbatest (pl. talajminta) vastagsága; $\varepsilon$ a dielektromos állandója (más néven relatív permittivitása, vagyis az a szám, amely megmutatja, hogy a próbatest anyagának permittivitása hányszorosa a vákuuménak).

Az elektromágneses hullámok a próbatest anyagáról részben visszaverődnek, részben át is haladnak rajta. Az áthaladás során csillapítást szenvednek, azaz csökken az energiájuk. Az energia a mintavastagsággal exponenciálisan csökken (ELLIS, 1987):

$$
E=E_{0} e^{-\beta d}
$$

ahol: $E_{0}$ és $E$ a hullám energiája a próbatest előtt és után, $\beta$ a csillapítási tényező.

Az általunk használt mikrohullámú készülék adójának hullámhossza $3 \mathrm{~cm}$, frekvenciája $10 \mathrm{GHz}$, teljesítménye pedig $10 \mathrm{~mW}$ volt.

\section{A hullámhossz és a rétegvastagság összefüggése}

Az interferencia lehetséges eseteinek elemzése azt mutatta, hogy az x eltolás mindig kisebb, mint a berendezés $\lambda$ hullámhosszának fele. Ennek figyelembevételé- 


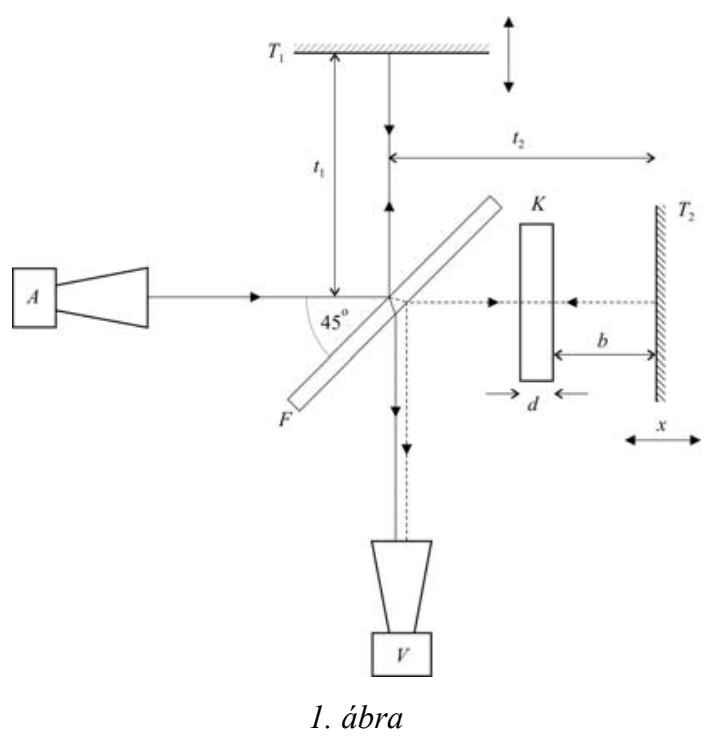

A mikrohullámú Michelson-interferométer összeállítási vázlata.

A: adó; V: vevő; $T_{1}$ és $T_{2}$ : tükrök; F: féligáteresztő- (osztó-) tükör; $K$ : próbatest

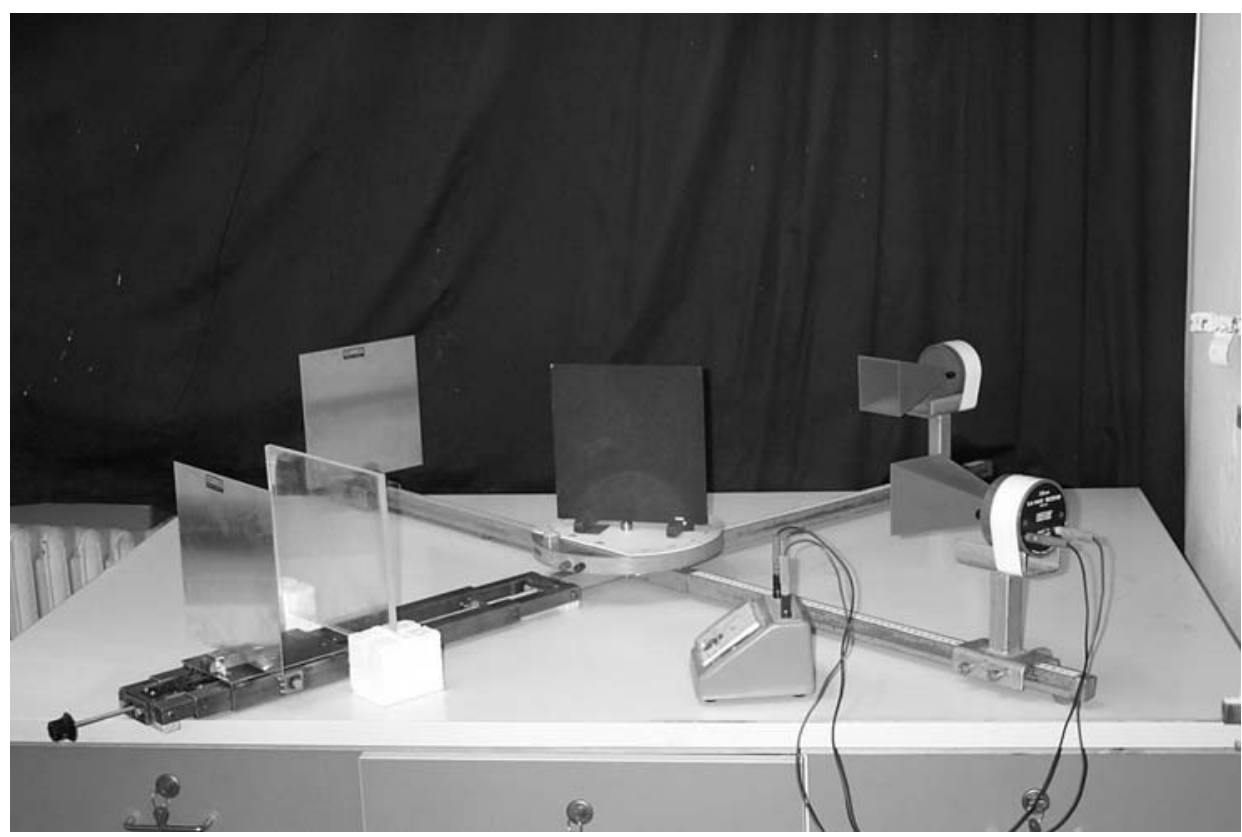

2. ábra

A mikrohullámú interferométer távlati képe (az elrendezés ugyanaz, mint az 1. ábrán, de a hullámutak sorrendje más: jobbra fent az adó, lent a vevő, középen az osztótükör, balra lent a $T_{2}$ tükör és a függőleges cella, fölötte a $T_{1}$ tükör) 
vel a dielektromos állandó az (1) egyenlet, valamint a próbatest vastagsága és a hullámhossz közötti összefüggés alapján kifejezhető:

$$
\lambda>2 d(\sqrt{\varepsilon}-1)
$$

Az adó (ld. 1. ábra) által kibocsátott jel frekvenciájától - hullámhosszától - függően a (3) egyenlőtlenség a próbatest d vastagságára ad felső korlátot, azaz:

$$
d<\frac{\lambda}{2(\sqrt{\varepsilon}-1)}
$$

Az interferométer adójának $\lambda=3 \mathrm{~cm}$ hullámhossza esetén a különbözö dielekromos állandójú minták mérhető vastagsága: tiszta víz $(\varepsilon=81)$ esetén $\mathrm{d}<$ $0,19 \mathrm{~cm}$; nedves homok $(\varepsilon=25)$ esetén $\mathrm{d}<0,38 \mathrm{~cm}$; plexi lemez $(\varepsilon=3)$ esetén $\mathrm{d}<$ $2,05 \mathrm{~cm}$.

\section{A homokminta viztartalmának meghatározása}

A vízszintes cellába töltött és vízzel telített homokminta tömegét mérlegen cg pontossággal mértük. Ventilátoros légárammal növeltük a minta száradási sebességét. A száradás során az $\varepsilon$-érték meghatározását követően súlymérésével határoztuk meg a homokminta víztartalmát. A térfogat százalékos víztartalmat $(\Theta)$ a tömegszázalékos érték és a térfogattömeg ismeretében adtuk meg.

\section{Eredmények}

Mérések függöleges cellával

A tiszta vízzel és nedves homokkal töltött cellákkal végzett méréssorozat célja a cellában lévő anyag dielektromos állandójának meghatározása volt. A méréseket a 2. ábra szerinti elrendezésben végeztük, 1 és $2 \mathrm{~mm}$ résméretü - azaz mintavastagságú - plexiből készült cellákkal. A minták $\varepsilon$-értékét az (1) egyenlettel számoltuk. A (4) egyenlőtlenséggel kapott becslésekből látható, hogy vízre a $2 \mathrm{~mm}$-es résméret már nagyobb, homokra azonban még belül van a hullámhossz-kritérium által megengedhető értéken. Ennek ellenére nem sikerült megbízható $\varepsilon$-értékeket mérni sem a tiszta vízre, sem a vízzel telített homokra. Ezért a berendezést átalakítottuk. A $\mathrm{T}_{2}$ tükör eltolását egyszerủ mérőléc helyett mikrométer-csavarral mozgatott szerkezettel végeztük (lásd a 2. ábrán). A mérési eredmények azonban az átalakítás után sem javultak. Az $\varepsilon$-értékek szórása jelentős maradt, és a mérések nehezen voltak reprodukálhatók.

A tapasztalt bizonytalanságot azzal magyaráztuk, hogy a cellában lévő anyagminta maga is visszaveri a mikrohullámokat. A víz reflexiója nagyobb, a vizes homoké kisebb mértékü. A plexi, vagy a papír pedig egyáltalán nem ver vissza mikrohullámokat. A reflexió mértéke tehát az $\varepsilon$-érték növekedésével nő. A függőleges mérőcella nedves homokkal, de különösen vízzel feltöltve maga is tükörként viselkedik. Hatása a $T_{2}$ tükörrel kombinálva bonyolult interferencia-kombinációkat 
eredményezhet a minta és a tükör közötti b távolság függvényében (1. ábra). Magyarázatunk igazolására a $\mathrm{b}$ távolságot a minta eltolásával változtattuk, aminek hatására a vevőben maximum- és minimumértékek váltakoztak a $3 \mathrm{~cm}$-es hullámhossznak megfelelő távolságközzel.

\section{Mérések ferde állású cellával}

A mérendő anyag nagy $\varepsilon$-értékéből adódó reflexió kiküszöbölésére a visszavert hullámot „kivezettük” a rendszerből. Ezt a cella függőleges síkjának $45^{\circ}$-os elforgatásával értük el. A mérési elrendezés ekkor a 2. ábráéval azonos, csupán a mérendő anyagot tartalmazó cella ferde. Ezzel az elrendezéssel mind a középső osztótükör, mind a cella mögötti $T_{2}$ tükör felé irányuló reflexió megszűnt. A mérések megbízhatósága és reprodukálhatósága jelentősen javult.

A víz és a nedves homok dielektromos állandójára azonban az irodalminál általában jóval kisebb értékeket kaptunk; vízre 60 körüli, vízzel telített homokra pedig 20 körüli értéket. Glicerinnel a mért érték $\varepsilon=20$ volt az irodalmi $\varepsilon=40$ helyett. Az eltérést ELLIS (1987) közleménye magyarázhatja, amely szerint, pl. a víz dielektromos állandója kb. $1 \mathrm{GHz}\left(10^{9} \mathrm{~Hz}\right)$ frekvenciáig állandó, értéke azonban a frekvencia növekedésével csökken. A jelenséget az okozza, hogy a poláros anyagokban a térerősség váltakozásának hatására a dipól-molekulák a gerjesztő frekvencia ütemében irányt váltanak. Igen nagy frekvenciánál azonban a dipólusok már nem követik a tér váltakozásának ütemét, ami a dielektromos állandó csökkenésében nyilvánul meg. Megjegyezzük, hogy az elterjedt talajnedvesség-mérési módszerek általában 1 GHz-nél jóval kisebb, kb. $150 \mathrm{MHz}$-es hatásos frekvenciát használnak (ROBINSON et al., 1999; RAJKAI, 2004). Az $\varepsilon$-értékek 1 GHz-nél nagyobb frekvenciákon történő csökkenése azonban nem zárja ki a módszer talajnedvesség-mérésre történő használatát. Kalibráció segítségével ugyanis az összetartozó értékek meghatározhatók.

\section{Ferde sugármenetes mérések}

A mérőcella plexifal anyagának dielektromos állandója kissé módosítja az interferenciaképet, továbbá a mikrohullám a plexi lemez külső és belső felületén is kismértékben reflektálódik, zavarva a mintáról történő reflexiót. Ennek kiküszöbölésére az interferométer mérési elrendezését ismét megváltoztattuk. Az új elrendezésben a cella helyett a mikrohullámú berendezés sugármenetét változtattuk meg, ferdítettük el oly módon, ahogy az a 3. ábrán látható. A reflektált hullámok ekkor sem játszanak szerepet a mérésben, valamint a cella vízszintesen helyezhető el. A mérendő minta vízszintes elhelyezésének előnye, hogy a mintaanyag tárolásához csupán oldalsó és alsó határoló lapok szükségesek. További előny, hogy a felül nyitott cellában az anyagminta vastagsága változtatható.

A 3. ábrán látható interferométeres mérésekhez homokbányai homokot használtunk, amelynek leggyakoribb szemátmérője $0,26 \mathrm{~mm}$, szervesanyag-tartalma nem volt, $\mathrm{pH}\left(\mathrm{H}_{2} \mathrm{O}\right)$-értéke: 8,5 , mésztartalma pedig $0,2 \%$. A vízszintes plexicellába töltött homok száraz térfogatsúlya $1.58 \mathrm{~g} / \mathrm{cm}^{3}$, hézagtérfogata $\mathrm{n}=0,41$, rétegvastagsága (d) pedig $3,1 \mathrm{~mm}$ volt. 


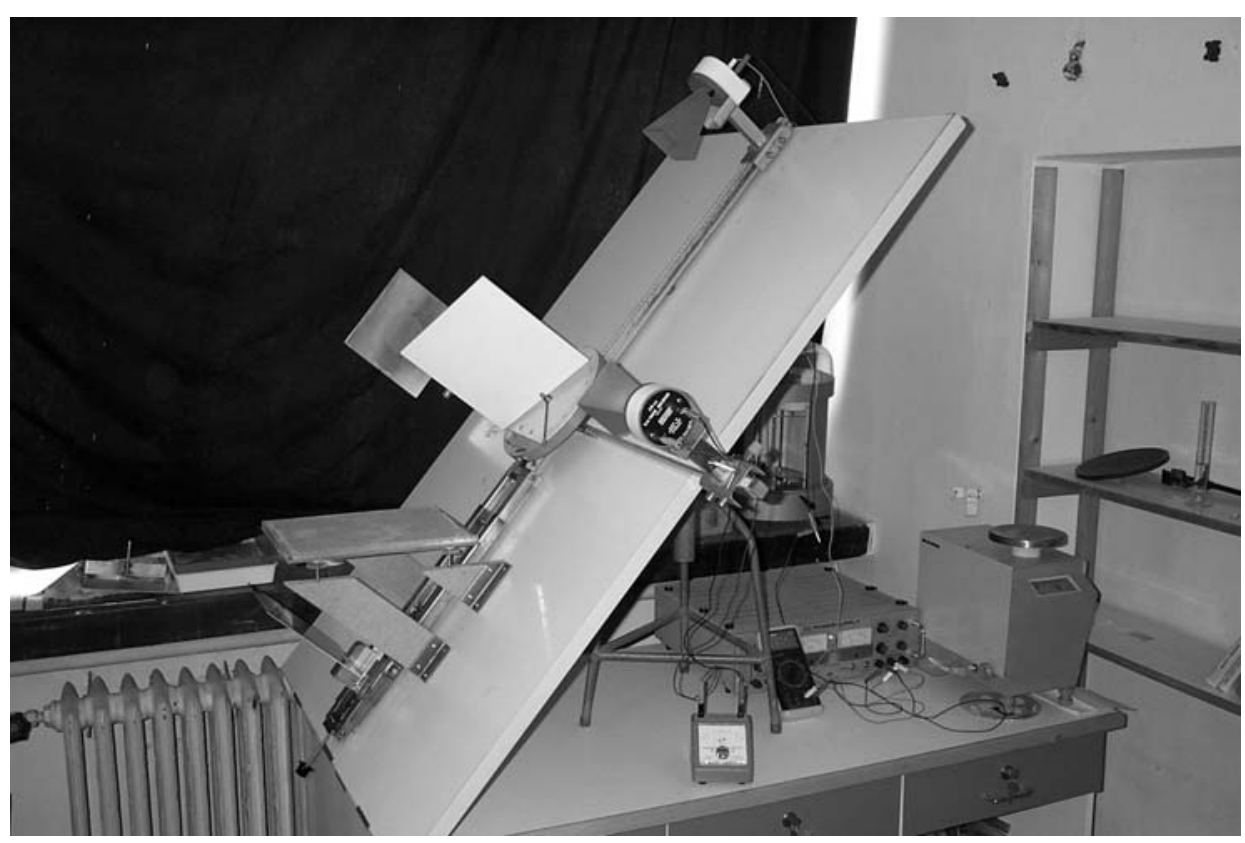

3. ábra

Homokminta dielektromos állandójának interferometriás mérése ferde elrendezésben (az adó fent, a vevő az állvány felénk eső szélén, a vízszintes minta az állvány alsó részén)

a) Nedves homok dielektromos állandójának mérése. - Víztelítettségi állapotból indulva, a homokréteget levegőn szárítottuk. A száradás során meghatároztuk a homokminta víztartalmát és a víztartalomhoz tartozó $\varepsilon$-értéket. Az ily módon mért $\varepsilon$-értékeket korrigáltuk a plexi fenéklemez okozta hatás kiszürésére. A mérés során ugyanis az adóból kiinduló mikrohullámfront kétszer halad át a homokrétegen és a plexi lemezen. A homokréteg korrigált dielektromos állandóját az (1) egyenlettel analóg módon írtuk fel:

$$
\varepsilon=\left[1+\frac{x}{d_{\mathrm{h}}}+\frac{d_{\mathrm{p}}}{\mathrm{d}_{\mathrm{h}}}\left(1-\sqrt{\varepsilon_{\mathrm{p}}}\right)\right]^{2}
$$

ahol: $\varepsilon$ a homok, $\varepsilon_{p}$ a plexi dielektromos állandója, $d_{h}$ a homok, $d_{p}$ a plexilemez vastagsága.

A homokminta korrigált $\varepsilon$-értékeit a térfogati nedvességtartalom $(\Theta)$ függvényében a 4. ábrán ábrázoltuk. A mért $\varepsilon$-értékeket a Topp-féle empirikus egyenlet alapján számított értékekkel hasonlítottuk össze, amihez a Topp-egyenlet alábbi alakját használtuk (TOPP et al., 1980):

$$
\varepsilon=3,03+9,3 \theta+146 \theta^{2}-76,7 \theta^{3}
$$


A 4. ábra azt mutatja, hogy a méréssel kapott értékek többnyire kisebbek a Topp-egyenlettel számított értékeknél. Ennek egyik lehetséges oka a már említett effektus, vagyis az interferométer adója $10 \mathrm{GHz}$ frekvenciáján a dielektromos állandó értéke csökken. Nem kizárható továbbá a talajfelszínről történő és a talaj nedvességtartalmával változó mértékü reflexió lehetősége sem.

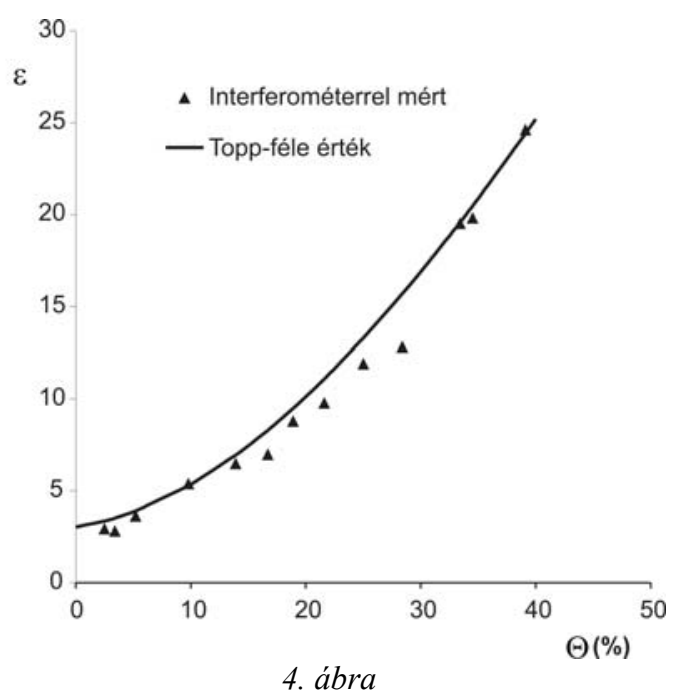

Homokminta dielektromos állandója $(\varepsilon)$ a térfogati víztartalom $(\Theta)$ függvényében

b) Nedves homok reflexiójának és abszorpciójának mérése. - A mérés során 1 $\mathrm{cm}$ vastag, kezdetben víztelített homokréteg reflexióját és abszorpcióját vizsgáltuk úgy, hogy a homokot ventilátoros levegőfúvással szárítottuk. A reflexiót az 5. ábra szerinti elrendezésben mértük. Az abszorpció mérésekor a vevőt a cella alatt helyeztük el. Az energiamegmaradás törvénye értelmében:

$$
E_{0}=E_{\mathrm{r}}+E_{\mathrm{a}}+E_{\mathrm{t}}
$$

ahol: $E_{o}$ a mintára beérkező, $E_{r}$ a reflektált, $E_{a}$ az abszorbeált, $E_{t}$ az átmenő mikrohullám energiája.

A mérés eredményeit a 6 . ábrán mutatjuk be. A vízszintes tengelyen a homok víztelítettségét, a függőleges tengelyen a vevőnél mért - a reflektált, illetve az átmenő mikrohullámmal arányos - áramerősséget ábrázoltuk. Az átmenő energia exponenciális csökkenést mutat. A (2) egyenlet szerint az átmenő energia a rétegvastagsággal exponenciálisan csökken. Itt a minta rétegvastagsága változatlan, de víztartalma a szárítás folytán csökken. A víztartalom csökkenése tehát a rétegvastagság csökkenésével ekvivalens. Ugyanakkor a reflektált energia a víztelítettséggel egyenletesen nö.

Az abszorbeált energia az 50\%-os víztelítettség környezetében maximumot mutat. Ennek magyarázata a következő lehet: Az interferometriás méréseinkből tudjuk, 


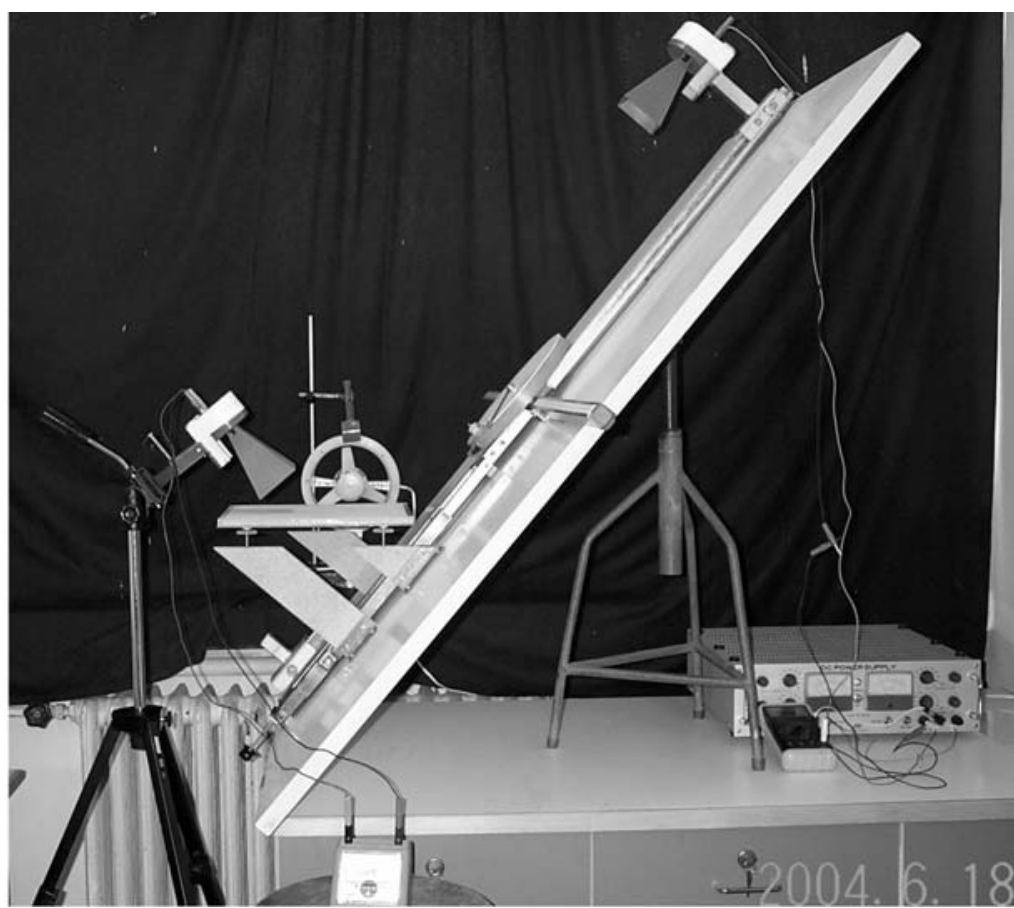

\section{5. ábra}

A mikrohullám reflexiójának mérése ferde állványon (jobbra fent az adó, alul a vízszintes minta, fölötte a vevő a visszavert hullám mérésére, háttérben a szárító ventilátor)

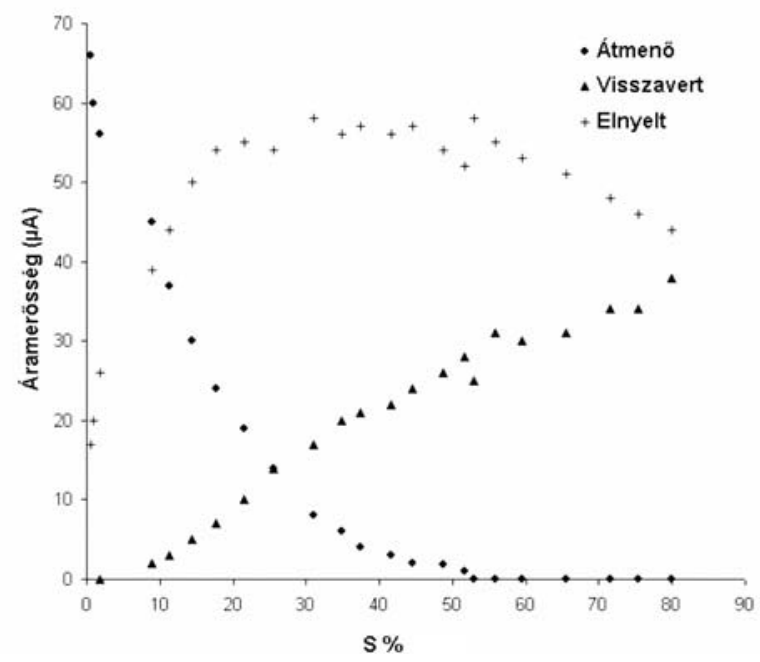

6. ábra

A reflektált, az abszorbeált és az átmenő jel nagysága a homok víztelítettségének függvényében 
hogy 50\%-os víztelítettségnél a minta dielektromos állandójának értéke 9 körüli. A mintába beérkező mikrohullám hullámhossza rövidülést szenved, mégpedig $\sqrt{ } 9$, azaz 3-szoros arányban. Az eredetileg $3 \mathrm{~cm}$-es hullámhossz tehát $1 \mathrm{~cm}$-re rövidül, ami pedig éppen megegyezik a minta vastagságával. Ebből az következik, hogy a mintába ferdén beérkező hullám többszörös teljes visszaverődést szenved, miközben erősítést okozó interferencia lép fel. A jelenség hasonló ahhoz, amikor a víztócsák tetején szétfolyt olajfoltok a fényhullámok interferenciája következtében tetszetős színes sávokat mutatnak. Ez a felerősített interferencia miatti hullámszóródás szintén oka lehet a homok 50\%-os víztelítettségnél megfigyelhető abszorpciós maximumának.

\section{A dielektromos állandó hömérsékletfüggése}

A homokminták nedvességtartalmának ventilátorral gyorsított párolgása következtében a hőmérséklet csökkenése nagyobb mértékủ volt, mint természetes száradáskor. A hőmérsékletcsökkenés maximális értéke az interferométeres méréseknél $3,1 \mathrm{~mm}$ vastag homokrétegre $3,2{ }^{\circ} \mathrm{C}$, az abszorpció-reflexió méréseknél használt 1 $\mathrm{cm}$ vastag homokrétegre pedig $4,4{ }^{\circ} \mathrm{C}$ volt. A megadott hömérsékletcsökkenés CHAPLIN (2005) grafikonjai alapján sorrendben $\Delta \varepsilon=1,5$ és $\Delta \varepsilon=2,5$ dielektromos állandó csökkenést idéz elő. A vizsgálatok jelenlegi szakaszában ezeket az $\varepsilon$ változásokat elhanyagolhatónak tekintettük. Nagyobb hömérsékletváltozások, pl. terepi mérések esetén azonban korrekciót kell alkalmazni.

\section{Következtetések, javaslatok}

A Michelson-féle (optikai) interferométer mikrohullámú változatát széles körben használják különböző anyagok dielektromos állandójának meghatározására. Jelen tanulmányban a berendezést talajnedvesség-mérésre alkalmaztuk. A tájékozódó mérések során kiderült, hogy a mintáról visszavert hullám az interferenciaképre és ezáltal a mérésekre zavarólag hat. A visszavert hullám okozta hibát a minta megdöntésével küszöböltük ki. Ferde sugármenetes mérési elrendezést alakítottunk ki, amellyel a mérési eredmények megbízhatóak és reprodukálhatóak lettek. 3,1 mm vastag víztelített homokréteg kiszáradását végig követve, a Topp-féle talaj $\varepsilon$ értékekhez közeli dielektromos állandókat kaptunk. Megállapítottuk, hogy a mikrohullámú hullámhossz-tartományban a vizsgálható talajréteg-vastagság korlátozott.

Közvetlen sugármenetes (nem interferometriás) összeállitásban a mintán átmenő és az arról reflektálódó hullámenergia meghatározását is elvégeztük. Az eredmények a fizikai elvárásokkal összhangban vannak. A módszer alkalmazása szempontjából bíztató, hogy a mérések szerint a reflektált energia és a víztartalom kapcsolata közel lineáris.

Összefoglalóan megállapítható, hogy:

- az interferometriás mérési elrendezés alkalmas a talaj víztartalmának meghatározására. Alkalmazása azonban kis rétegvastagságokra korlátozódik; 
- a közvetlen sugármenetes reflexiómérés is alkalmasnak látszik a talaj víztartalmának mérésére. Ebben a mérési megoldásban nincsenek talajréteg-vastagsági korlátok. Mindkét mérési eljárás gyakorlati, kiváltképp terepi alkalmazása további kutató-fejlesztő munkát igényel.

Kulcsszavak: talajnedvesség, dielektromos állandó, mikrohullám, reflexió

\section{Irodalom}

BuZÁS I. (szerk.), 1993. Talaj- és agrokémiai vizsgálati módszerkönyv 1. A talaj fizikai, vízgazdálkodási és ásványtani vizsgálata. INDA 4231 Kiadó. Budapest.

CHAPLIN, M., 2005. Water dielectric and microwave radiation. http://sbu.ac.uk/water/ microwave.html

DiRKsen, C., 1999. Soil Physics Measurements. Catena Verl. Reiskirchen.

ELLIS, D., 1987. Well Logging for Earth Scientists. Elsevier. New York-AmsterdamLondon.

PATKÓ GY. (szerk.), 1991. Fizikai praktikum. Tankönyvkiadó. Budapest.

RAJKAI K., 2004. A víz mennyisége, eloszlása és áramlása a talajban. MTA Talajtani és Agrokémiai Kutatóintézet. Budapest.

Robinson, D. A., GARDNER, C. M. K. \& COOPER, J. D., 1999. Measurement of relative permittivity in sandy soils using TDR, capacitance and theta probes. Journal of Hydrology. 223. 198-211.

TopP, G. C., DAVIS, J. L. \& ANNAN, A. P., 1980. Electromagnetic determination of soil water content: Measurement in coaxial transmission lines. Water Resources Res. 16. $574-582$.

Érkezett: 2005. október 19. 


\title{
Soil Moisture Measurements using a Microwave Michelson Interferometer
}

\author{
${ }^{1}$ L. UJFALUDI, ${ }^{2}$ K. RAJKAI, ${ }^{1}$ J. VIDA, ${ }^{3}$ C. SZOMBATHY and ${ }^{1}$ G. ZOLLER \\ ${ }^{1}$ Eszterházy Károly College, Eger, ${ }^{2}$ Research Institute for Soil Science and Agricultural \\ Chemistry of the Hungarian Academy of Sciences, Budapest and ${ }^{3}$ Budapest Technical and \\ Economics University, Budapest
}

\section{Summary}

The microwave version of the Michelson (optical) interferometer is widely used to determine the dielectric constant $(\varepsilon)$ of various substances. In the present work the instrument was used to measure soil water content. Preliminary measurements revealed that waves reflected from the sample had a disturbing effect on the interference image and thus on the measurements. This error was eliminated by tilting the sample. When measurements were made with an inclined image beam path the results were reliable and reproducible. Dielectric constants close to Topp's soil $\varepsilon$ values were obtained when the drying out of a $3.1 \mathrm{~mm}$ water-saturated sand layer was monitored. The soil layer thickness that can be examined in the microwave wavelength range was found to be limited.

When the wave energy passing through the sample and that reflected from it were determined in a direct image beam path (non-interferometric) set-up the results were in accordance with physical expectations. It is promising for the utility of the method that measurements showed the relationship between the reflected energy and the moisture content to be near-linear.

It can be concluded that the interferometric equipment is suitable for the determination of soil water content, but only in the case of thin layers. Reflection measurements using a direct image beam path also appear to be suitable for the determination of soil water content. With this method there are no soil layer thickness limits. Further research and development will be required before the methods can be put into practice.

Fig. 1. Outline of the microwave Michelson interferometer equipment. A: transmitter; V: receiver; $\mathrm{T}_{1}$ and $\mathrm{T}_{2}$ : mirrors; F: semi-permeable (beam-splitting) mirror; K: sample body.

Fig. 2. Perspective view of the microwave interferometer (the arrangement is the same as in Fig. 1, but the order of the wave paths is different: transmitter: top right, receiver: bottom right, splitting mirror: centre, $T_{2}$ mirror and vertical cell: bottom left, $\mathrm{T}_{1}$ mirror: top left).

Fig. 3. Interferometric measurement of the dielectric constant of a sand sample using inclined equipment (transmitter: top, receiver: near side of the stand, horizontal sample: lower part of the stand).

Fig. 4. Dielectric constant $(\varepsilon)$ of the sample as a function of the volumetric water content $(\Theta)$.

Fig. 5. Measurement of microwave reflection on an inclined stand (transmitter: top right, horizontal sample: bottom, above it: receiver to record reflected waves, background: drying ventilator).

Fig. 6. Magnitude of the reflected, absorbed and transmitted signals as a function of the water saturation of the sand. 